\title{
Analisis Sentimen Masyarakat Terhadap Kinerja Persatuan Sepakbola Seluruh Indonesia Menggunakan Metode Backpropagation
}

\author{
Ripki Puja Ika Putra1', Muhamad Akbar², Rahayu Amalia³ \\ 1,2Informatics Departement, Bina Darma University, Palembang, Indonesia \\ 3 Information Systems Departement, Bina Darma University, Palembang, Indonesia \\ Email: ripkipujaikaputra@gmail.com¹', muhamad.akbar@binadarma.ac.id² , \\ rahayu_amalia@binadarma.ac.id³
}

\begin{abstract}
Sentiment analysis in a sentence describes the part of the consideration of an entity or a event regarding the product, service, topic, issue, person, organization, or event that becomes the target object in sentiment sentences. Judging from several reasons for positive and negative sentiments originating from social media, researchers will use social media not only to communicate between friends, but will be used as a means to find out an aspiration for the community, especially the Indonesian community regarding legal issues or problems related to government. One of the aspirations that will be analyzed is the performance of PSSI. In analyzing this, researchers using the Backpropagation Method are learning methods to reduce error rates by adjusting their weight based on the desired output and target differences. Backpropagation is also a systematic method for multilayer training in Artificial Neural Networks. Backpopagation is said to be a multilayer training method because Backpropagation has three layers in the training process, namely input layer, hidden layer and output layer.
\end{abstract}

Keywords: Social Media, Hastag, Backpropagation.

\section{PENDAHULUAN}

Dalam perkembangannya kinerja Persatuan Sepak Bola Seluruh Indonesia atau disebut PSSI yang dibawah Kepemimpinan Ketua Umum Pangkostrad ada yang memiliki sentimen positif,negatif maupun netral. seperti penilaian oleh suporter Persis Solo masih jauh dari harapan, PSSI disebutnya belum berbenah maupun mengarah maju dan lebih baik. Masih jauh dari harapan. Memang awalnya terlihat optimistis bisa mengarah lebih baik, namun dalam perjalanan masih banyak kekurangan, seperti Perjalanan kompetisi baik Liga 1 maupun Liga 2 
masih diwarnai hal-hal kontroversial. Seperti dari kompetisi kasta tertinggimendapat kasus dengan sanksi yang dijatuhkan Komdis PSSI. Sementara Liga 2, beberapa kasus besar yang terjadi semisal keputusan kontroversial yang menggelar babak permainan tertutup aatau play-off. Selain itu terdapat masalah gelaran babak 8 besar yang ditunda dari jadwal awal yang mengalami penundaan yang lama dalam permainan.

Dilihat dari beberapa alasan sentimen positfi dan negatif yang bersumber dari media sosial. Media sosial adalah sebuah sarana yang dibuat untuk memudahkan interaksi sosial dan komunikasi dua arah. Dengan semua kemudahan yang diberikan oleh media sosial ini,penyebaran informasi dari satu individu ke individu lain menjadisangat mudah [1]. peneliti akan memanfaatkan sosial media yang tidak hanya untuk berkomunikasi antara teman saja, akan tetapi dijadikan sebuah sarana untuk mengetahi suatu aspirasi bagi masyarakat. Banyak deskripsi yang dituliskan oleh para pakar mengenai pengertian masyarakat. Dalam bahasa Inggris dipakai istilah society yang berasal dari kata Latin socius, berarti "kawan". Istilah masyarakat sendiri berasal dari akar kata Arab syaraka yang berarti "ikut serta, berpartisipasi". Masyarakat adalah sekumpulan manusia saling bergaul, atau dengan istilah ilmiah saling berinteraksi. khususnya masyarakat indonesia mengenai masalah hukum ataupun masalah yang berhubungan dengan pemerintahan [2]. Salah satu aspirasi yang akan dianalisa ini yaitu tranding mengenai kinerja dari PSSI. Dari permasalahan ini peneliti akan menganalisa dari kinerja PSSI untuk mendapatkan setimen apa yang terjadi pada masyarakat baik itu sentimen positif maupun sentimen negatif.

Analisis sentimen pada suatu kalimat menggambarkan bagian pertimbangan penilaian terhadap entitas atau kejadian tertentu [3]. Dalam menganalisa ini peneliti menggunakan Metode Backpropagation adalah metode pembelajaran untuk memperkecil tingkat error dengan cara menyesuaikan bobotnya berdasarkan perbedaan output dan target yang diinginkan. Backpropagation juga merupakan sebuah metode sistematik untuk pelatihan multilayer Jaringan Syaraf Tiruan. Backpopagation dikatakan sebagai metode pelatihan multilayer karena Backpropagation memiliki tiga layer dalam proses pelatihannya, yaitu imput layer, hidden layer dan output layer, dimana backpropagation ini merupakan perkembangan dari single layer network (Jaringan Layar Tunggal) yang memiliki dua layer, yaitu input layer dan output layer [4]. 


\section{METODOLOGI PENELITIAN}

Metode penelitian merupakan suatu cara yang dapat digunakan untuk mencapai tujuan yang diharapkan melalui suatu penelitian dengan teknik-teknik dan alatalat tertentu. Adapun metode yang digunakan dalam penelitian ini yaitu metode development research adalah suatu kegiatan penelitian yang bertujuan dan berusaha mengembangkan atau melengkapi pengetahuan yang sudah ada atau diketahui. Permasalahan manusia dan lingkungan alamnya selalu berkembang yang kesemuanya ini harus memperoleh jawaban yang simbang [5].

\subsection{Pengambilan Data}

Crawling adalah suatu teknik yang digunakan untuk mengumpulkan informasi yang ada dalam web. Crawling bekerja secara otomatis, dimana informasi yang dikumpulkan berdasarkan atas kata kunci yang diberikan oleh pengguna. Alat yang digunakan untuk melakukan crawling disebut dengan crawler. Crawler berbentuk program yang diprogram dengan algoritma tertentu, sehingga dapat melakukan pemindaian ke halaman -halaman web, sesuai dengan alamat web ataupun kata kunci yang diberikan pengguna.

Pada saat melakukan pemindaian, crawler akan membaca teks yang ada, hyperlink dan berbagai tag yang digunakan di halaman web tersebut. Berdasarkan informasi tersebut, crawler akan mengindeks informasinya atau pun menyimpan informasi tersebut ke dalam sebuah file atau ke dalam database. Ilustrasi proses crawling ditunjukkan pada

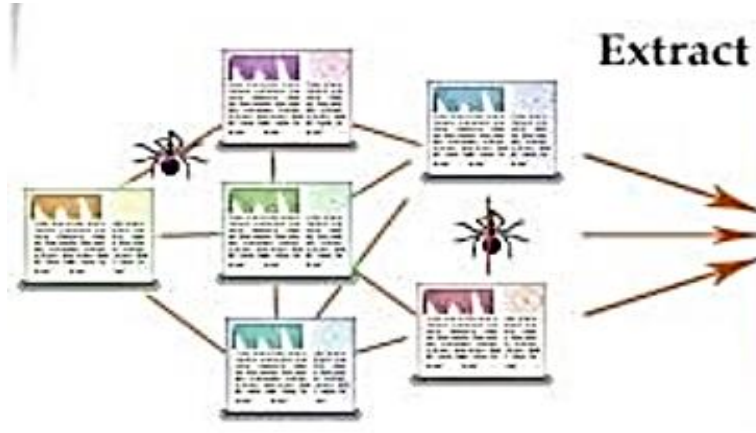

Web Crawling

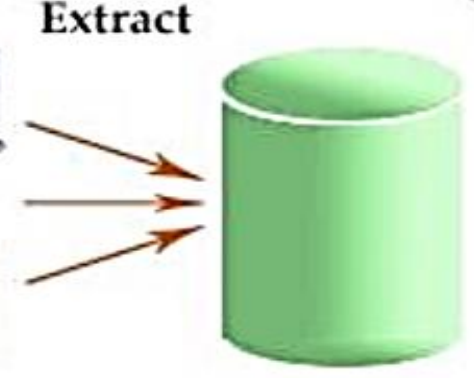

Database

Gambar 1. llustrasi proses Crawling 
Twitter crawling merupakan penerapan teknik crawling pada media sosial Twitter. Teknik ini bertujuan untuk mengumpulkan data Twitter dari media sosial Twitter. Dari data yang telah dikumpulkan, dapat dianalisa dan diambil informasi penting yang bermanfaat bagi pengguna. Untuk menerapkan teknik Twitter crawling ini, pihak Twitter telah memberikan akses bagi pengguna untuk memanfaatkan Twitter API. Sehingga dengan memanfaatkan Twitter API tersebut, pengguna bisa dengan mudah memperoleh data-data seperti Twitter, data pengguna dan lain-lain. Untuk selanjutnya dikumpulkan dan disimpan dalam sebuah file atau basis

Berikut ini dijelaskan secara bertahap tentang proses yang dilakukan oleh peneliti dalam mengimplementasikan teknik crawling. Diawali dengan cara membuka hak akeses Twitter API, dilanjutkan dengan pemanfaatan Dan tahap terakhir adalah mencari kemudian menyimpan data yang sudah ditemukan kedalam file atau database. Berikut ini adalah penjelasannya :

1) Memperoleh akses Twitter adalah Hal pertama yang harus dilakukan oleh pengguna adalah membuat akun Twitter. Tujuannya untuk memperoleh API Key, API Secret, Access Token dan Access Token Secret. Langkah-langkah memperoleh key tersebut adalah sebagai berikut:

a. Membuat akun Twitter, apabila pengguna belum memilikinya

b. Mengakses https://apps.Twitter.com/ kemudian log in menggunakan akun yang telah dibuat sebelumnya.

2) Menghubungkan dengan Twitter Searching API dengan aplikasi TAG Setelah dilakukan import, selanjutnya adalah menghubungkan apkikasi yang sedang dikembangkan dengan Twitter, caranya adalah memasukkan \#sentimen.

3) Menyimpan data kedalam file atau database Setelah aplikasi dijalankan, maka hasil dari crawling disimpan dalam file, berupa CSV, XLS atau ke dalam database.

\subsection{Data Twitter}

Setelah melalui tahap pra-proses pada sentimen masyarakat terhadap Kinerja Persatuan Sepak Raga Seluruh Indonesia dilakukan perhitungan dengan menghitung nilai probabilitas teks berdasarkan basis pengetahuan yang dimiliki. Terdapat dua teks yang akan diklasifik. 
Tabel 1. Data Tweet

\begin{tabular}{lll}
\hline No. & Data Tweet & Sentimen \\
\hline 1. & @deni: yang tua, muda dukung PSSI \#pssi & Positif \\
2. & @jitunews: kinerja kacau belum pas \#pssi & Negatif \\
3. & $@$ TeukuDiciawi: hadir \#pssi & Netral \\
\hline
\end{tabular}

\subsection{Hasil Preprocessing}

Data latih yang digunakan akan dilakukan tahap preprocessing seperti case pada sentimen masyarakat terhadap Kinerja Persatuan Sepak Raga Seluruh Indonesia dengan hasil sebagai berikut ini :

Tabel 2 Hasil Preprocessing

\begin{tabular}{lllll}
\hline \multicolumn{3}{c}{ Kata } \\
\hline Yang & Tua & Muda & dukung & PSSI \\
kacau & Belum & Pas & & \\
hadir & Pssi & & \\
\hline
\end{tabular}

\subsection{Pembentukan Fitur}

Dari hasil preprocessing, dilakukan pembentukan fitur sentimen masyarakat terhadap kinerja Persatuan Sepak Raga Seluruh Indonesia,yaitu menentukan kata yang memiliki nilai sentimen, seperti berikut :

Tabel 2.3 Pembentukan Fitur

\begin{tabular}{llll}
\hline Data & Fitur (Kemunculan) & Kelas Sentimen & \\
\hline D1 & Yang $(1), \quad$ tua(1), & Netral, positif, positif, \\
& muda(1),dukung(1) & positif & \\
D2 & $\begin{array}{l}\text { kinerja(1), kacau(1), } \\
\text { belum(1), pas(1) }\end{array}$ & Netral, negatif, & negatif, \\
& Hadir, kinerpssi & Netral, Netral & \\
\hline
\end{tabular}

2.5 Perhitungan Nilai Probabilitas Setiap Kelas

Menghasilkan nilai perhitungan probabilitas Sentimen Masyarakat Terhadap Kinerja Persatuan Sepak Raga Seluruh Indonesia. 
Tabel 2.4 Perhitungan Nilai Probabilitas Setiap Kelas

\begin{tabular}{llllll}
\hline Kelas & Data(j) & & & $F d(C j)$ & $P(C j)$ \\
Sentimen & D1 & D2 & D3 & & \\
\hline Positif & 3 & 1 & 0 & 2 & $4 / 4$ \\
Negatif & 0 & 2 & 0 & 1 & $2 / 4$ \\
Netral & 1 & 1 & 2 & 2 & $4 / 4$ \\
\hline
\end{tabular}

\section{HASIL DAN PEMBAHASAN}

\subsection{Hasil}

Dalam melakukan proses crawling peneliti menggunakan aplikasi TAGS v6.1 yang berbasis web untuk mengambil data dari twitter dengan tahapan yaitu ketikkan : https://tags.hawksey.info/get-tags/. Kemudian dillakukan koneksi ke google dan twitter untuk hak akses akun yang kita miliki untuk menghubukan aplikasi TAGS v6.1 dengan twitter dalam proses mengambil data. Data yang diperoleh dilakukan selama 10 hari yang dapat dilihat pada tabel dibawah ini :

Tabel 3.1 Jumlah data yang crawling

\begin{tabular}{ccc}
\hline No & Urutan Hari Crawling & Jumlah Data \\
\hline 1. & Hari Ke-1 & 13 \\
2. & Hari Ke-2 & 100 \\
3. & Hari Ke-3 & 549 \\
4. & Hari Ke-4 & 640 \\
5. & Hari Ke-5 & 679 \\
6. & Hari Ke-6 & 695 \\
7. & Hari Ke-7 & 235 \\
8. & Hari Ke-8 & 174 \\
9. & Hari Ke-9 & 221 \\
10. & Hari Ke-10 & 105 \\
& & TOTAL \\
\hline
\end{tabular}

Dilihat dari tabel diatas jumlah data secara keseluruhan yaitu sebanyak 3411 data, akan tetapi peneliti hanya mengambil 1000 data dengan persentase dari 
data yang diambil secara random, dari total keseluruhan jumlah data berdasarkan persentase error sebesar 3\%. Dalam proses pengambilan data peneliti menggunakan aplikasi TASG V6.1.9 dilanjutkan dengan mengetikkan hastag yang akan diambil datanya pada kotak enter term dan diketik \#PSSI.

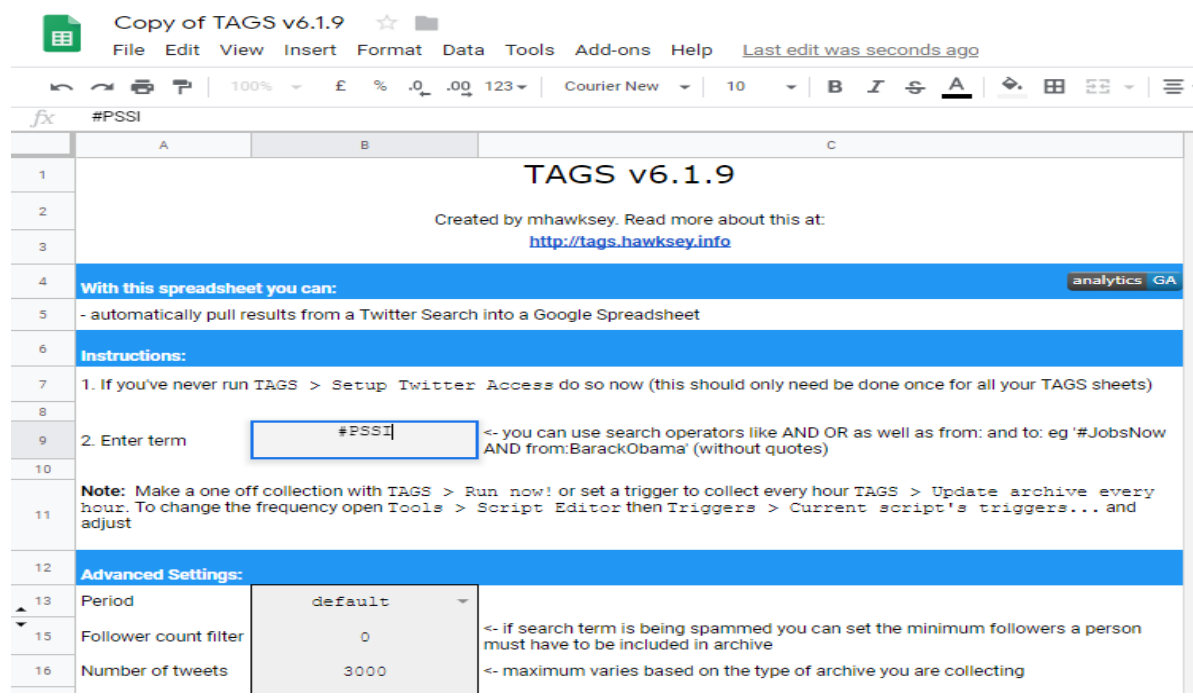

Gambar 2. ketikkan hastag yang akan dilakukan crawling

Setelah mengetikkan hastag dilanjutkan dengan memilih menu TAGS dan pilih Run row, sehingga akan melakukan proses loading mengambil data pada twiter.

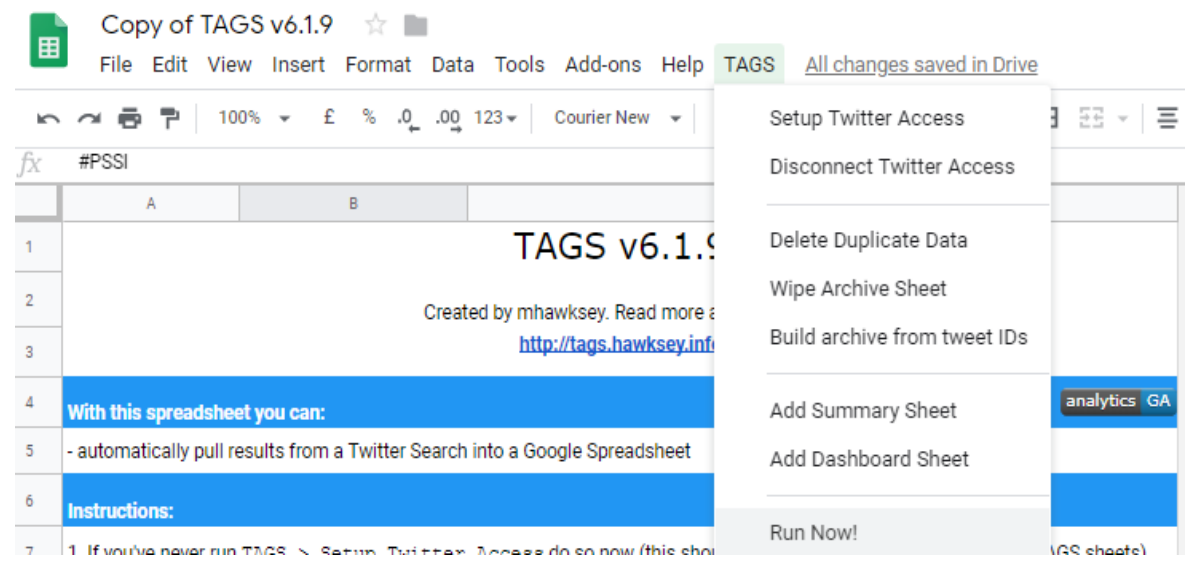

Gambar 3. Pilih menu Run Row 
Setelah dilakukan proses training maka menghasilkan pengemlompokan data berdasarkan sentimen apakah positive, negative dan netral.

\begin{tabular}{|c|c|c|}
\hline 1 & Sentimen & Status \\
\hline 2 & Liga Spanyol ( BolaUtama ) \#SepakBolalndonesia \#ISL \#PSSI & Netral \\
\hline 3 & $\begin{array}{l}\text { RT @bornINmalang: @EdanBolaRCBFM } \\
\text { CEO, Pemilik, ato pengurus Club yang laen..... yg masih Umyek di \#pssi Bgmn? }\end{array}$ & Negative \\
\hline 4 & Liga Italy ( BolaUtama ) \#SepakBolalndonesia \#ISL \#PSSI & Netral \\
\hline 5 & $\begin{array}{l}\text { PIALA INDONESIA TARKAM NASIONAL } \\
\text { \#SOS-22012019- Maksud hati ingin kembali menggelar \#Pialalndonesia yang terakhir }\end{array}$ & Negative \\
\hline 5 & Liga Inggris EPL ( BolaUtama ) \#SepakBolalndonesia \#ISL \#PSSI & Netral \\
\hline 7 & $\begin{array}{l}\text { Sepuhnya \#pssi minta revolusi tapi isinya dan yg menjalankan revolusi tetep antek2 } \\
\text { JD dkk https://t.co/FFYr2djntr }\end{array}$ & Negative \\
\hline 3 & RT @147crew_: \#PSSI-GOBLOG \#FEDERASI-BOBROK & Negative \\
\hline Э & $\begin{array}{l}\text { Satu langkah menatap masa lalu@MataNajwa @NajwaShihab } \\
\text { \#MataNajwaPSSIBisaApa3 }\end{array}$ & Netral \\
\hline
\end{tabular}

Gambar 6. Hasil Pengelompokan Sentimen

Analisa ini berakhir dengan melakukan proses datamining yang sesungguhnya, makahasil yang dicapai oleh penulis adalah untuk memprediksi Sentimen Masyarakat Terhadap Kinerja PSSI berdasarkan data Sentimen Masyarakat Terhadap Kinerja PSSI dalam memudahkan proses datamining ini peneliti menggunakan aplikasi weka dari tabel sentimen yang menampung data Sentimen Masyarakat Terhadap Kinerja PSSI yang kemudian menghasilkan informasi data Netral, Positif dan Negatif.

\subsection{Pembahasan}

Pada bab ini akan dibahas dalam proses pencarian informasi Ekstraksi data akan dilakukan dengan menggunakan aplikasi weka. Aplikasi ini tidak memiliki koneksi kesebuah database karena dataset yang akan dimasukan dianggap sudah bersifat statis atau tidak ada perubahan nilai atau atribut. Dataset yang akan diolah diharuskan bertipe CSV (comma separated values). Hasil dari datamining ini adalah informasi yang nantinya dijalankan dengan menggunakan weka. Adapun informasi ini memiliki sub-sub menu sebagai berikut: 


\subsubsection{Explorer}

Explorer data akan dilakukan dengan menggunakan aplikasi weka. Proses ini akan digunakan untuk memilih file yang diolah melalui file csv.

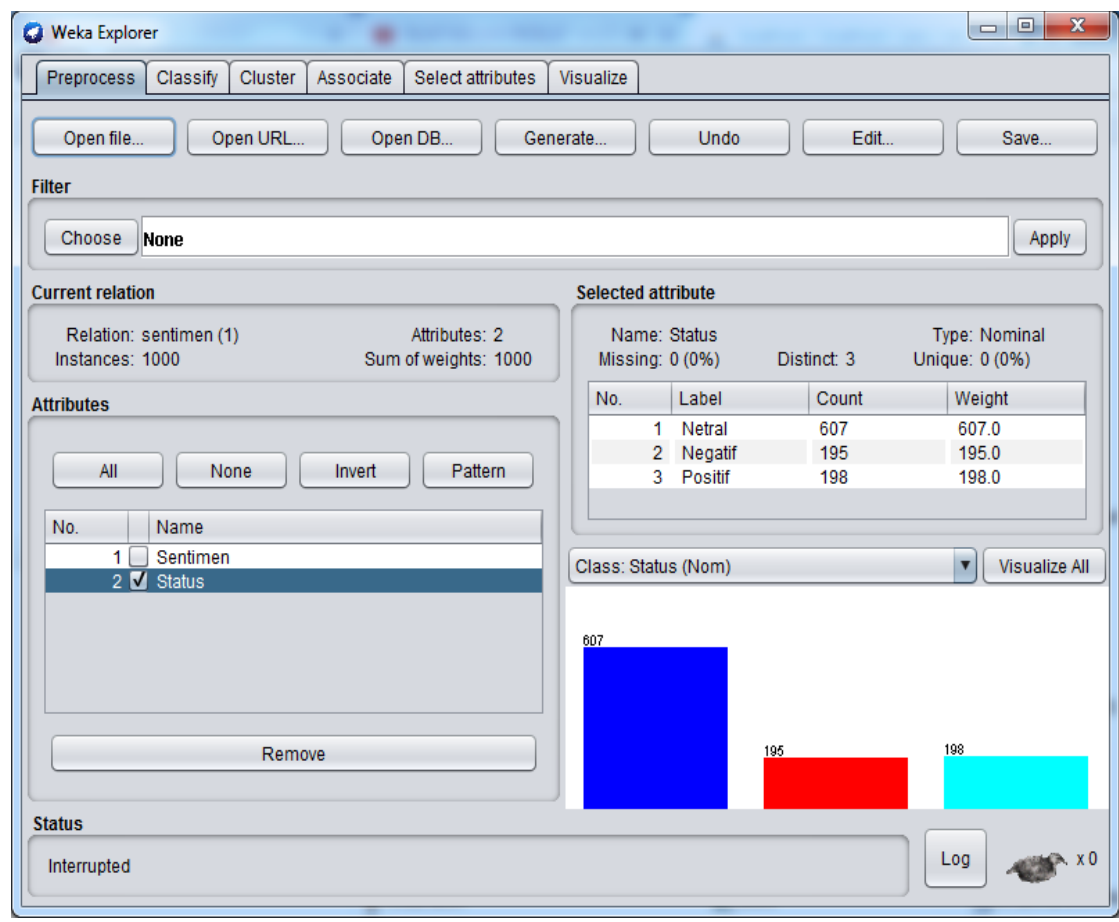

Gambar 7. Proses Explorer

Gambar diatas menjelaskan mengenai data yang dilakukan proses mining berdasarkan field sentimen dan status apakah positif, negatif dan netral sebanyak 1000 record.

\subsubsection{Preprocess}

Preprocess data akanmenampilkan field apasaja yang akan dicari informasinya dengan menggunakan aplikasi weka. Proses ini akan digunakan untuk memilih salah satu field yang digunakan. 


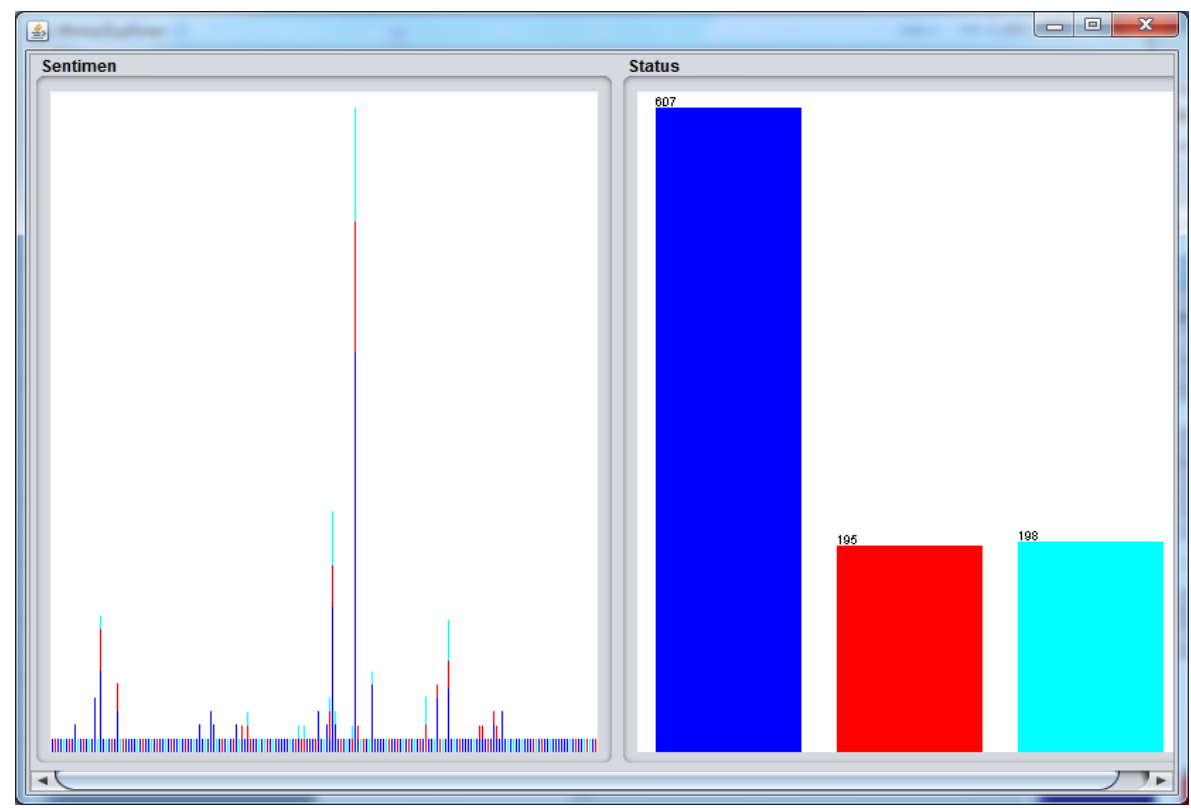

Gambar 8. Proses Prepocess

Gambar diatas menjelaskan mengenai data yang dilakukan proses mining dengan menampilkan 2 kolom grafik, dimana kolom pertamana mengenai data sentimen dan kolom kedua menampikan informasi status sentimen yang mana warna biru sentimen netral, merah negatif dan biru muda positif yang menjelaskan berdasarkan grafik batang nilai sentimen mana yang paling besar. Dilihat dari grafik batang grafik berwarna biru nilai yang paling besar dengan status sentimen netral.

\subsubsection{Classify}

Classify data akandilakukandenganmenggunakanaplikasiweka. Proses ini digunakan untuk membuat class mengenai data Sentimen Masyarakat Terhadap Kinerja PSSI.ClassifySentimen Masyarakat Terhadap Kinerja PSSI Netral, Negatif dan Positif data akandilakukandenganmenggunakanaplikasiweka. Proses ini digunakan untuk membuat class mengenai data sentimen berdasarkan Sentimen Masyarakat Terhadap Kinerja PSSI. 


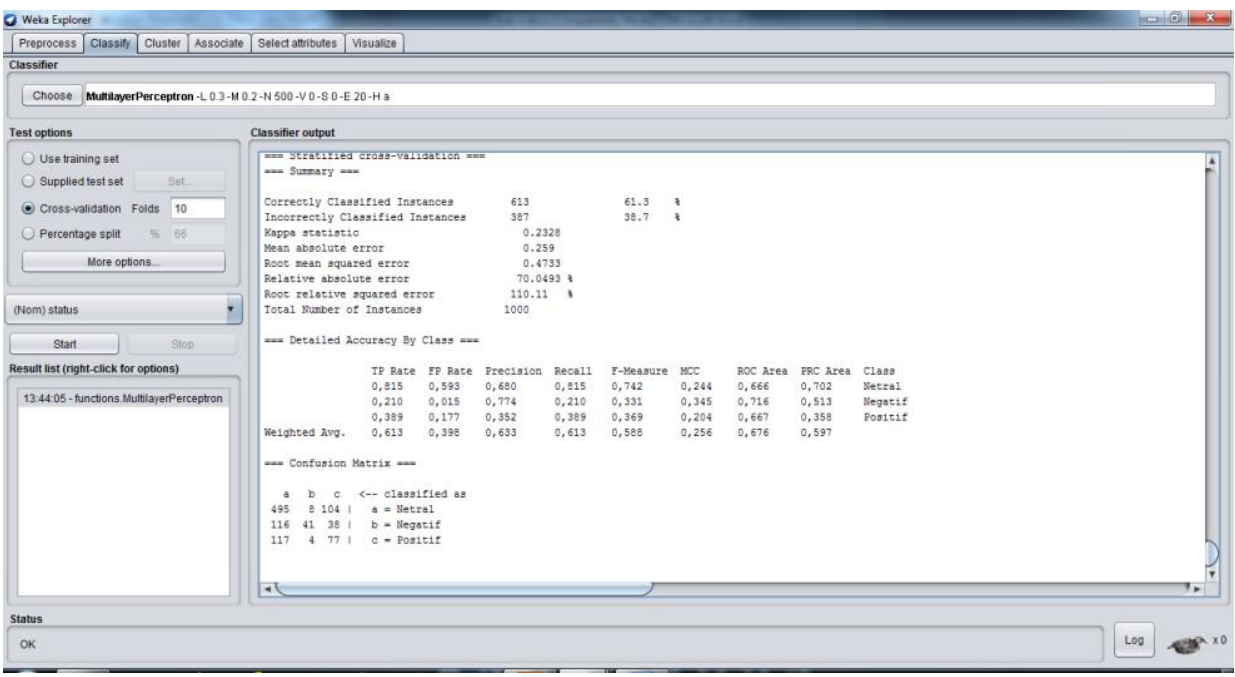

Gambar 9. Proses Jumlah Sentimen

Gambar diatas menjelaskan mengenai data yang dilakukan proses mining berdasarkan mengunakan algoritma multilayerperpception dengan nilai class netral PRC Area 0,702 lebih tinggi hasil proses algoritma dibandingkan standar nilai weighated avg sebesar 595, nilai class negatif PRC Area 0,513 lebih rendah dibandingkan standar nilai weighated avg sebesar 595 dan nilai class positif PRC Area 0,358 lebih rendah dibandingkan standar nilai weighated avg sebesar 595.

\section{KESIMPULAN}

Berdasarkan hasil penelitian penulis yang dilakukan serta pembahasan yang dilakukan oleh penulis maka dapat diambil kesimpulan bahwa :

1) Sesuai dengan tujuan dari skripsi ini yaitu analisis Sentimen Masyarakat Terhadap Kinerja PSSI yang dapat digunakan untuk melakukan evaluasi apakah yang sangat berpengaruh berpengaruh besar terhadap masyarakat.

2) Proses evaluasi diharapkan dapat memudahkan mendapatkan informasi mengenai data Sentimen Masyarakat Terhadap Kinerja PSSI yang paling banyak berdasarkan kategori yaitu netral, negatif, positif

3) Hasil yang didapat dari data Sentimen Masyarakat Terhadap Kinerja PSSI berdasarkan kriteria netral sebanyak 607 data dengan nilai prediksi 60,7\%, negatif nilai sebanyak 195 data dengan prediksi 19,5\% dan positif nilai sebanyak 198 data dengan prediksi 19,8\%. 
Daftar Pustaka

[1] Paramitha Cindy Rizal Putri, "Analisis Faktor Pengaruh Promosi BerbasisSosial Media Terhadap Keputusan Pembelian Pelanggan dalam BidangKuliner," 2011.

[2] Koentjaraningrat, Pengantar ilmu antropologi. Jakarta, Indonesia: Rineka Cipta, 2009.

[3] Pang Bo and Lee Lillian, "Opinion Mining And Sentiment Analysis," Foundations and Trends in Information Retrieval, vol. 2, no. 1-2, 2008.

[4] T Sutojo and Edi Mulyanto, Kecerdasan buatan. Yogyakarta, 2011.

[5] Supardi, Metodologi Penelitian Ekonomi \& Bisnis. Yogyakarta, Indonesia: UII Press, 2005. 